\title{
Medical Students' Knowledge and Attitude towards Research in Ain Shams University: A cross-sectional Study
}

\author{
Maha M. Wahdan ${ }^{(1)}$, Dina A. Gamal Eldin ${ }^{(1)}$, Osama M. Mohy Eldin(2), Eslam M. Amin ${ }^{(2)}$, \\ Esraa A. Abdelrasoul ${ }^{(2)}$, Mostafa M. Shalaby ${ }^{(2)}$ \\ ${ }^{1}$ Community, Environmental and Occupational Medicine, Faculty of Medicine, Ain Shams \\ University. \\ ${ }^{2}$ Medical students, Faculty of Medicine, Ain Shams University.
}

\begin{abstract}
:
Background: Training for research skills and practicing of research early in career has increased to resolve the health care problems and help physicians in taking career decisions. But, unfortunately, number of researchers has declined significantly in the last decades especially in developing countries.Objectives: This study was carried out to assess the knowledge and attitude towards scientific research among medical students in Ain Shams University. Methods: A cross-sectional study was carried out from October to November 2016. Convenient sample of medical students from each grade $\left(1^{\text {st }}\right.$ grade to $6^{\text {th }}$ grade) were asked to participate. Data were collected via a predesigned, pretested and validated self-administered questionnaire including 3 parts about sociodemographic data, knowledge and attitude towards research questions. Results: A total 312 questionnaires were completed. Students showed moderate level of knowledge and attitude (mean score $43.4 \pm 22.5$ and $45.8 \pm 18.6$, respectively). knowledge improved significantly with increasing years of study (higher among Students of 6th, 5th and 4th grades than other grades) and Male students knowledge was higher than females. While students of 3rd and 1st grades showed high attitude towards practicing research than other grades. Conclusions: There is a gap in students' knowledge and attitude towards research. There is need to improve the existing medical education curriculum to foster research culture among students. Also, there is need to encourage students to carry out research through active participation in research projects in university.
\end{abstract}

Keywords: Attitude, knowledge, undergraduate medical students, research

*Corresponding author: E-mail: Mostafa.shalaby.212@gmail.com 


\section{Wahdan et al: Knowledge, attitude towards research}

Introduction: In the fast moving world, research has become important intellectual equipment for the human beings to change their life style according to the needs and necessities of the society. Research opens new frontiers in all the fields like medicine. ${ }^{(1)}$ Medical knowledge and training should be up-to-date as they are important for doctors in their duty of care for patients and provide the best available effective treatment based on the 'best available evidence'. Also, every doctor should contribute in the generation of evidence by conducting research. ${ }^{(2)}$

Thus, understanding and use of scientific methods is an important component of medical profession. So, Research training courses in medical education curricula was introduced as a method to increase students' awareness about research, along with their research skills, independent learning, and ability to publish research papers. And also help students to identify their future careers, performing and presenting their own research, able to evaluate and select relevant articles and secure better residency positions. $^{(3)}$

Additionally, early exposure of medical students to clinical research activities fosters their intentions to join an academic medical career. Even if medical students do not

Egyptian Family Medicine Journal (EFMJ) choose to practice clinical research, research knowledge will improve their ability to make evidence based decisions in clinical practice. A systematic review of the literature by Straus et al. showed that having a medical school publication positively influences academic career choice among medical students. ${ }^{(4)}$

Unfortunately, the insufficient attention to research by a government and the educated members of a community may contribute to scientific and knowledge lags. The shortfall in basic and valuable research may reflect factors as attitude to, knowledge of and barriers toward research. ${ }^{(5)}$ One of the most important factors for conducting a research is the researchers' beliefs, where attitude to health research come from the researchers' curiosity and interest in a particular subject or their wish to solve a problem within a community, then the adequate knowledge about research principles. The final factor affecting the performance of research lies in the barriers against researchers. Some previous studies of medical students showed that they had inadequate knowledge of the scientific inquiry process. ${ }^{(5)}$

Despite researchers importance, their number has been in a documented decline since the early 1990s. Researchers from the

Vol .3(1),May $2019 \quad$ www.efmj-eg.org 


\section{Wahdan et al: Knowledge, attitude towards research}

developing world represent about $37.4 \%$ of total world research community. In 2010, there were 4673.2 researchers per million inhabitants in the USA compared to 420.4 researchers per million inhabitants in Egypt. Arab institutions published only 76417 reports in the period between 1996 and 2012 , which is equal to $4 \%$ of medical research reports published by US based institutions in the same period. ${ }^{(6,7,8,9)}$

In Egypt, review of literature showed that there are previous studies regarding knowledge, attitudes, and practices toward medical research among undergraduate students and their results revealed that there is a relatively low knowledge scores and low participation. ${ }^{(3)}$ For that reason, the aim of conducting this study was to assess the current knowledge and attitude towards scientific research among medical students in Ain Shams University so that programs and schemes could be developed to raise the profile of research in clinical practice.

Methods: A cross-sectional study was conducted among medical students, Ain Shams University in Egypt. A sample of 312 medical students was enrolled from each grade (6 grades) at Faculty of Medicine, Ain Shams University. No exclusion criteria were assigned. The educational model at most Egyptian medical

Egyptian Family Medicine Journal (EFMJ) schools consist of 6 years of studying: basic medical sciences (academic years) during the first three preclinical years and clinical sciences (clinical years) during the final three years. Medical students at the Faculty of Medicine, Ain Shams University obtain a mandatory clinical research course during the 4th year of enrollment, in which they study biostatistics, scientific writing, and searching for and appraising the evidence and recently, the second year students take a course about fundamentals of research and statistics.

Sampling technique: The students were asked to participate through taking convenience sample from each grade to have a sample of medical students represent both academic (students in grades 1-3) and clinical groups (students in grades 4-6). We required a sample size of 258 subjects to fulfill the objectives of our study at a $95 \%$ confidence level.

This sample size was calculated assuming a 50\% prevalence of good knowledge and attitude among undergraduate students, 5\% bond-on error, and $10 \%$ non-response rate. An anonymous pre-tested, structured questionnaire was adapted from questionnaire validated by Vodopivec et.al. and Khan et.al. ${ }^{(10,11)}$ The questionnaire consisted of three parts: 
1- Demographic information such as: age, gender, type of high school course, Academic year, participation in research projects.

2- Knowledge of research was investigated through 10 questions to evaluate basic and preliminary knowledge about research studies, sample, scientific writing, and database resources. Each correct response earned a score of 1 and each incorrect answer received a score of 0 . For each individual, score of individual questions was summed and then converted into percentage to represent the knowledge score.

3- Attitudes towards research were assessed by 6 questions. Each favorable attitude earned a score of 1 and each unfavorable attitude received a score of 0 . For each individual, score of individual questions was summed and then converted into percentage to represent the attitude score.

A pilot study was conducted after translating the questionnaire on Ten medical students to assess clarity. Based on the comments and suggestions of the respondents received adjustments were made on the wordings of the questions in the questionnaire.

Data management:Data were analyzed using Statistical Package for Social Sciences

Egyptian Family Medicine Journal (EFMJ)
(SPSS) version 20 for windows. Prior to analysis, the data was checked for accuracy of data entry and missing values. Data were summarized by count and percentage for categorical data and mean and standard deviation for continuous data. Statistical inference was drawn using the independent $t$ test and one-way ANOVA for comparing means between groups for continuous variables. A value of $p<0.05$ was considered significant.

Results: A total of completed questionnaires were received from 312 undergraduate medical students. Among the study population, $139(44.6 \%)$ respondents were males and 173 (55.4\%) were females. Distribution of students over grades is shown in Table 1. Proportion of subjects with correct answer for each question on knowledge and attitude questionnaire was shown in Table 2 and table 3.

As regards knowledge about research principles; only $32.4 \%$ and $38.8 \%$ students knew the definition of research hypothesis and theory respectively, whereas $36.2 \%$ students knew the MEDLINE and 28.8\% know the right way to search on previous publication. Nearly half (55.8\%) students know what is meant by essential charactristics of science, $51.9 \%$ of them know the rule of introduction part and

Vol .3(1),May $2019 \quad$ www.efmj-eg.org 


\section{Wahdan et al: Knowledge, attitude towards research}

$33.0 \%$ of them know the importance of representivness.

As regards attitude towards research; forty one percent students had previous experience of research projects, whereas $16.0 \%$ had written scientific papers; and $26.0 \%$ are filling confident when interpreting and writing a research paper. The overall mean student scores for knowledge and attitude were $43.4 \pm 22.5$ and $45.8 \pm 18.6$, respectively. And the proportion of students in quartiles of knowledge and attitude scores is shown in

\section{Table 4.}

As regards the factors affecting scores; male students had greater knowledge and attitude scores than females; but with no statistical significant difference. There is significant relation between scores and the students'garde; where the mean knowledge score of $5^{\text {th }}$ grade students was significantly greater than that of $1^{\text {st }}, 2^{\text {nd }}$, and $3^{\text {rd }}$ students $(\mathrm{P}=0.026,0.007 \& 0.003)$ respectively.

Likewise, there is significant relation between type of secondary schools attended by students and the attainable scores where the mean knowledge and attitude scores in medical students attended governmental secondary schools significantly lower than that of international schools' students $(\mathrm{P}=0.003 \& 0.008)$ respectively.

Egyptian Family Medicine Journal (EFMJ)
Discussion: This study reports moderate level of knowledge towards research [mean score 43.4\%] where about $62 \%$ of the students were falling in the middle two quartiles of the knowledge score. Similar trends were demonstrated by the students on the attitude score [mean score $=45.8 \%$ ]. Our findings are comparable and similar with the results of Vodopivec et al., Khan et.al, and Abushouk et.al where similar questionnaire was conducted among first year Croatian medical students and Pakistani medical students, respectively. Croatian medical students showed a similar mean knowledge ( $43.4 \%$ vs. $44 \%)$, but a lower mean attitude (45.8\% vs. $62.5 \%)$ score.

On the other hand, Pakistani medical students showed both high mean scores of knowledge and attitude (49\% \& 53\%, respectivily); This discrepancy may be explained by the baseline affect of secondary and high school education on medical students and in Pakistani medical collage, there is a satisfactory contribution of medical curriculum in developing research skills among medical students through wellstructured intensive training where Pakistani Students are taught theoretical essentials of research methodology, statistics and epidemiology during the first two years of their medical

Vol .3(1),May $2019 \quad$ www.efmj-eg.org 


\section{Wahdan et al: Knowledge, attitude towards research}

curriculum then followed by extensive community health projects undertaken by groups of students during year 4 and 5 . During these projects, students are involved in designing and implementing their research questions, analyzing their data and writing a detailed report of their project. Several of these studies get published in indexed journals..$^{(4,10,11)}$

Students'Knowledge about research: In the current study, only $32.4 \%$ and $38.8 \%$ students knew the definition of research hypothesis and theory respectively, whereas $36.2 \%$ students knew the MEDLINE and $28.8 \%$ knew the right way to search on previous publication. Nearly half of $(55.8 \%)$ students knew what is meant by essential charactristics of science, $51.9 \%$ of them knew the rule of introduction part and $33.0 \%$ of them know the importance of representivness. The findings of Vodopivec study were similar to ours, reporting that there is lack of knowledge on the scientific method and communication in medicine. ${ }^{(10)}$

Students' attitude towards research: In the current study, $81.1 \%$ of them think that undergraduate students should participate in research. Similar finding about attitude towards research was found in study conducted in university in Saudi Arabia where students agreed that 'research is

Egyptian Family Medicine Journal (EFMJ) important for identifying and investing problems in a subject matter'.(13)

About $41 \%$ of the students had previous experience of research projects apart from mandatory academic projects. Also, our results differ from results of Ibrahim et. al, study in Suez Canal University and Ain Shams University where a high percent of Suez Canal University (SCU) students had participated in research projects, because it was a part of an advanced research methodology course. Also, students were involved in the problem-based system education and were more likely to be involved in research.

While, in Ain Shams University nearly two thirds of students participated in simple tasks like data collection, $63.5 \%$ participated in cross sectional studies, and $11 \%$ had published papers in international Journals. About two thirds of students $(73.6 \%$ of ASU \& $62.4 \%$ of SCU students) thought that participation in research would facilitate their long term career goals. Approximately $20 \%$ of the surveyed students at each university thought that involvement in research activities was not relevant to medical education. More than $70 \%$ of students agreed that research would be an aspect of their future career. Low Participation in research in our study may be

Vol .3(1),May $2019 \quad$ www.efmj-eg.org 
explained by specifying the participation in research apart from mandatory academic projects in the used questionnaire. High participation thoughts among our study students' may be due to they thought about improving their long term career. ${ }^{(3)}$

Twenty six per cent of our students felt confident when interpreting and writing a research paper, $23.1 \%$ think that they can plan and conduct research project without supervision. While, our findings percentage differ from results in a study conducted by Vodopivec, et al. study where about $90 \%$ of medical students had a feeling of confidence in the interpretation and writing a research paper and $28.4 \%$ of them didn't need any assistance. ${ }^{(10)}$

Whereas only $16.0 \%$ of students participated in the current study had written scientific papers. In another study conducted in Saudi Arabia by Ibrahim and his colleagues, only $5.8 \%$ published a scientific paper. ${ }^{(14)}$

\section{Factors affecting knowledge and attitude}

towards research: In the current study, male students had greater knowledge and attitude scores than females; but with no statistical significant difference ( $p>0.05)$. Likewise, Ibrahem et. al study and where gender did not have a significant effect on students' knowledge nor attitudes. However,

Egyptian Family Medicine Journal (EFMJ) according to Khan and his colleagues gender was not a significant predictor of knowledge on health research, but, as regards attitude, males had a significant higher score than females. On the otherhand, In Amgad et. al study, males had a higher probability in the publishing of research projects than females. Unlike to the previous findings, in study conducted in Saudi Arabia, Female students showed significantly more positive attitude towards research $(\mathrm{P}<0.05){ }^{(3,11,12,13)}$

In the present study, students' knowledge about research improved significantly with increasing years of medical education, as the mean knowledge score of $5^{\text {th }}$ grade students was significantly greater than that of $1^{\text {st }}, 2^{\text {nd }}$, and $3^{\text {rd }}$ students $(\mathrm{P}=0.026,0.007 \& 0.003)$ respectively and this may be explained by the contribution of medical curriculum in the development of research skills through training and the improvement of research culture. While, attitude score is higher in the first academic 3 years than the 3 clinical years.

Unlike Khan study, there is significant difference between knowledge and attitude scores between conventional LBL (year 4 and5) students and PBL (year 1 to 3) students and these scores also increased with higher year of study. ${ }^{(11)}$ Our study noted that there is significant difference in knowledge

Vol .3(1),May $2019 \quad$ www.efmj-eg.org 
and attidue scores between different types of secondary schools attended by medical students, where scores were lower in those attended governmental secondary schools than that of international schools' students $(\mathrm{P}=0.003 \& 0.008)$ respectively. similar to these finding Abushouk et.al study where different high school backgrounds showed difference in the extent of research participation as students who studied in international schools expressed more willingness to conduct clinical research in the future, compared to students from public or private schools. Whereas, Khan study found that type of high school course was not a significant predictor of knowledge or attitude about research. ${ }^{(4,11)}$

Study limitations:As mentioned earlier, convenience sampling method was used for filling up of questionnaires including only 312 students, thus the students who completed the survey may not reflect the knowledge and attitudes of all medical students. Also, the study participants were drawn from one university in Cairo, Egypt, the sample population does not fully represent all university students across Egypt.

Therefore, a better study design could have been adopted using random stratified sampling method from different types of

Egyptian Family Medicine Journal (EFMJ) universities in different governorates. Second, we did not include the questions that reflect barrires against knowledge, attitude and practice towards medical research to put evidence based solutions.

Conclusions: In the present study, it was found that students had unsatisfactory knowledge and attitude towards research. There is a need to improve the existing medical education curriculum to foster research culture among students. Formal evaluation should also be done during university examinations, to ensure that resident doctors learn these aspects. Also, there is a need to encourage students to carry out research during their undergraduate educational program. A system of rewarding the best research may be started. Conferences and workshops specially organized for students should be fostered.

Acknowledgment: I would like to express my great appreciation to Osama Mohamed Mohy Eldin, Eslam Mohamed Amin, Esraa Ahmed Abdelrasoul and Mostafa Mahmoud Shalaby for their assistance in the literature reviews and data collection.

Conflict of interests: We confirm that there are no known conflicts of interest associated with this publication.

Funding: There has been no financial

Vol .3(1),May $2019 \quad$ www.efmj-eg.org 


\section{Wahdan et al: Knowledge, attitude towards research}

support for this work that could have influenced its outcome.

\section{References:}

1. Sureshkumar K. Attitude towards research among medical education students. International Journal of Multidisciplinary Research and Development. 2015; Volume: 2, Issue: $8,85-87$

2. Dattatray B. Pawar, Suchita R. Gawde, and Padmaja A. Marathe . Awareness about medical research among resident doctors in a tertiary care hospital: A cross-sectional survey. Perspectives in Clinical Research 2012; 3(2): 57-61. Retrieved from: https://www.ncbi.nlm.nih.gov/pmc/articles/P MC3371549/. (Accessed 12 August 2018).

3. Ibrahim SI, Afifi AM, Zahran A. Knowledge, attitudes and practices of medical students towards research in two public universities in Egypt. Proceedings of the IRES 23rd International Conference, Dubai, UAE, 29th December 2015, ISBN: 978-93-85832-92-5. Retrieved from: http://www.worldresearchlibrary.org/up_pro c/pdf/130-145206235634-39.pdf. (Accessed 12 August 2018).

4. Abushouk AI, Hatata AN, Omran IM, Youniss MM, Elmansy KF, Meawad AG. Attitudes and perceived barriers among medical students towards clinical research: A cross-sectional study in an Egyptian medical school. Journal of Biomedical Education. 2016; Article ID 5490575, 7 pages. $\quad$ Retrieved from: https://www.hindawi.com/journals/jbe/2016/ 5490575/. (Accessed 20 August 2018).

5. Memarpour M, Fard AP and Ghasemi R. Evaluation of attitude to, knowledge of and barriers toward research among medical science students. Asia Pacific Family Medicine 2015; 14:1. Retrieved from: https://apfmj.biomedcentral.com/articles/10. 1186/s12930-015-0019-2. (Accessed 08 August 2018).

6. Solomon SS, Tom SC, Pichert J, Wasserman D, Powers AC. Impact of medical student research in the development of physicianscientists. J Invest Med. 2003; 51(3):14956.

7. UNESCO. UNESCO science report 2010: The current status of science around the world. UNESCO Publishing 2010. Retrieved from:

http://books.google.com/books?hl=en\&lr=\& $\mathrm{id}=2 Z T L C O e \_f q w C \& o i=f n d \& p g=P R 4 \& d q$ $=$ UNESCO+science+report+2010:+The+cur rent+status+of+science+around+the+world \&ots=ZG6xT3RFER\&sig=NLecZ3GFCHg QQnRDWfawfIlLxf0. (Accessed 26 July 2018).

8. UNDP. Human Development Report 2013. The rise of the south: human progress in a

Vol .3(1),May $2019 \quad$ www.efmj-eg.org 
Wahdan et al: Knowledge, attitude towards research

diverse world. United Nations Development Program 2013. Retrieved from: http://hdr.undp.org/sites/default/files/reports/ 14/hdr2013_en_complete.pdf. (Accessed 08 August 2018).

9. El-Azami-El-Idrissi M, Lakhdar-Idrissi M, Ouldim K, Bono W, Amarti-Riffi A, Hida $\mathrm{M}$, Nejjari C. Improving medical research in the Arab world. Lancet 2013; 382(9910), 2066

10. Vodopivec I, Vujaklija A, Hrabak M, Lukiæ IK, Marušiæ A, Marušiæ M. Knowledge about and attitudes towards science of first year medical students. Croat Med J 2002; 43:58-62. Retrieved from: http://docplayer.net/62045783-Knowledgeabout-and-attitude-towards-science-of-firstyear-medical-students.html. (Accessed 10 July 2018).

11. Khan H, Khawaja MR, Waheed A, Rauf MA and Fatmi Z. Knowledge and attitudes about health research amongst a group of Pakistani medical students. BMC Medical Education 2006, 6:54. doi: 10.1186/14726920-6-54. Retrieved from: https://bmcmededuc.biomedcentral.com/arti cles/10.1186/1472-6920-6-54. (Accessed 10 July 2018).

12. Amgad M, Tsui MMK, Liptrott SJ, Shash E. "Medical student research: an integrated mixed-methods systematic review and metaanalysis,"PLoSONE 2015; 10 (6), ArticleID e0127470.

13. Althubaiti A, Al Muqbil B, Al Buraikan D. Assessment of medical students' attitudes towards research and perceived barriers. International Journal of Medical Students 2017; 5 (3). Retrieved from: https://www.ijms.info/index.php/IJMS/articl e/view/28. (Accessed 10 July 2018).

14. Ibrahim NKR, Fetyani DM, Bashwari J. Assessment of the research-oriented knowledge, attitude and practice of medical students and interns of the King Abdulaziz University, Jeddah and the adoption of a research intervention educational program. Rawal Medical Journal 2013; 38 (4). Retrieved from: https://www.ejmanager.com/mnstemps/27/2 7-1433255378.pdf. (Accessed 20 July 2018). 
Wahdan et al: Knowledge, attitude towards research

Table(1): Demographic characteristics of the studied population $(n=312)$

\begin{tabular}{|c|c|c|}
\hline Variables & $\mathrm{N}(\%)$ & Mean \pm SD (range) \\
\hline Age & & $20.7 \pm 1.7(17.0-25.0)$ \\
\hline \multicolumn{3}{|l|}{ Gender } \\
\hline - Male & $139(44.6 \%)$ & \\
\hline - Female & $173(55.4 \%)$ & \\
\hline \multicolumn{3}{|l|}{ Grade } \\
\hline - Grade 1 & $45(14.4 \%)$ & \\
\hline - Grade 2 & $53(17.0 \%)$ & \\
\hline - Grade 3 & $54(17.3 \%)$ & \\
\hline - $\quad$ Grade 4 & $54(17.3 \%)$ & \\
\hline - Grade 5 & $74(23.7 \%)$ & \\
\hline - Grade 6 & $32(10.3 \%)$ & \\
\hline \multicolumn{3}{|l|}{ Secondary School attended } \\
\hline - Governmental & $218(69.9 \%)$ & \\
\hline - Private & $58(18.6 \%)$ & \\
\hline - International & $36(11.5 \%)$ & \\
\hline
\end{tabular}


Wahdan et al: Knowledge, attitude towards research

Table(2): Medical students' response towards knowledge domains

\begin{tabular}{|c|c|}
\hline Statements & $\begin{array}{c}\mathrm{N}(\%) \\
\text { of correct answers }\end{array}$ \\
\hline - How would you define the scientific hypothesis? & $101(32.4 \%)$ \\
\hline - How would you define scientific theory? & $121(38.8 \%)$ \\
\hline - How would you define the scientific truth? & $27(8.7 \%)$ \\
\hline - The essential characteristic of science.... & $174(55.8 \%)$ \\
\hline $\begin{array}{l}\text { - A scale from } 1 \text { to } 5 \text { (like grades on an examination) is } \\
\text { called.... }\end{array}$ & $82(26.3 \%)$ \\
\hline - Representativeness is a key characteristic of... & $103(33.0 \%)$ \\
\hline - MEDLINE is........ & $113(36.2 \%)$ \\
\hline $\begin{array}{l}\text { - You have published a paper in a prestigious Journal of } \\
\text { Immunology to check the number of citations your } \\
\text { paper has received. The best way is search through } \\
\text { the...... }\end{array}$ & $90(28.8 \%)$ \\
\hline - The part of a scientific paper is.... & $111(35.6 \%)$ \\
\hline $\begin{array}{l}\text { - All listed rules apply to the process of writing an } \\
\text { Introduction section of a scientific paper... }\end{array}$ & $162(51.9 \%)$ \\
\hline
\end{tabular}


Wahdan et al: Knowledge, attitude towards research

Table (3): Medical students' response towards attitude domains

$\left.\begin{array}{|l|r|}\hline \multicolumn{1}{|c|}{\text { Statement }} & \multicolumn{1}{|c|}{\begin{array}{c}\text { N\%) } \\ \text { of favorable attitude }\end{array}} \\ \hline \text { - Do you feel confident in interpreting and writing } \\ \text { a research paper? }\end{array}\right)$


Wahdan et al: Knowledge, attitude towards research

Table (4): Medical students' knowledge and attitude percentage scores and levels distribution

\begin{tabular}{|l|r|r|}
\hline \multicolumn{1}{|c|}{ Variable } & N $(\%)$ & Mean \pm SD (range) \\
\hline Knowledge score & & $43.4 \pm 22.5(0-100)$ \\
\hline Knowledge score categories & & \\
\hline - $\quad$ Equal or less than 25\% & $128(41.0 \%)$ & \\
\hline - $26 \%-50 \%$ & $65(20.8 \%)$ & \\
\hline - 51\% - 75\% & $19(6.1 \%)$ & \\
\hline Mttitude percentage score & & $45.8 \pm 18.6(0-100)$ \\
\hline Attitude score categories & $215(68.9 \%)$ & \\
\hline - Equal or less than 25\% & $45(14.4 \%)$ & \\
\hline - 26\% - 50\% & $23(7.4 \%)$ & \\
\hline - 51\% - 75\% & & \\
\hline - More than 75\% & & \\
\hline
\end{tabular}


Table(5): Factors affecting medical students' knowledge and attitude scores

\begin{tabular}{|c|c|c|}
\hline Variables & Knowledge score & Attitude score \\
\hline \multicolumn{3}{|l|}{ Gender $^{\dagger}$} \\
\hline Male & $43.4 \pm 23.8$ & $48.0 \pm 19.3$ \\
\hline Female & $43.4 \pm 21.4$ & $44.0 \pm 17.9$ \\
\hline$P$ value & 0.997 & 0.063 \\
\hline \multicolumn{3}{|l|}{ Grade $^{\#}$} \\
\hline - Grade 1 & $40.3 \pm 19.6$ & $47.8 \pm 20.9$ \\
\hline - $\quad$ Grade 2 & $38.9 \pm 21.5$ & $47.5 \pm 16.5$ \\
\hline - $\quad$ Grade 3 & $37.7 \pm 20.7$ & $50.0 \pm 20.5$ \\
\hline - $\quad$ Grade 4 & $45.4 \pm 24.1$ & $43.8 \pm 16.3$ \\
\hline - Grade 5 & $49.7 \pm 21.6$ & $42.1 \pm 18.6$ \\
\hline - Grade 6 & $47.3 \pm 26.5$ & $44.8 \pm 18.2$ \\
\hline P value & 0.018* & 0.119 \\
\hline \multicolumn{3}{|c|}{ Academic/ clinical years ${ }^{\dagger}$} \\
\hline - Academic years & $38.90 \pm 20.524$ & $48.46 \pm 19.215$ \\
\hline - Clinical years & $47.73 \pm 23.411$ & $43.23 \pm 17.664$ \\
\hline P value & $0.000 *$ & $0.013 *$ \\
\hline \multicolumn{3}{|c|}{ Secondary school attended ${ }^{\#}$} \\
\hline - Governmental & $41.6 \pm 21.8$ & $44.4 \pm 18.1$ \\
\hline - Private & $44.2 \pm 22.8$ & $46.3 \pm 19.5$ \\
\hline - International & $53.5 \pm 23.8$ & $53.2 \pm 19.0$ \\
\hline P value & $\mathbf{0 . 0 1 2} *$ & $0.030 *$ \\
\hline
\end{tabular}

$\dagger$ independent t test, \# ANOVA test, * Statistically significant $(P$ value $\leq 0.05)$ 
Wahdan et al: Knowledge, attitude towards research

الملخص العربى

المعارف والأتجاهات نحو البحث العلمي بين طلبة كلية الطب بجامعة عين شمس : دراسة مقطعية

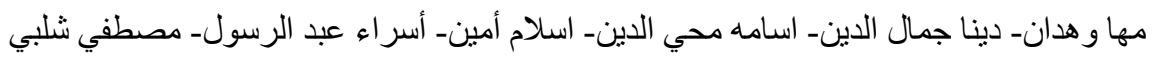

الخلفية: ازداد التدريب على المهارات البحثية و ممارسة البحث في مرحلة مبكرة من الحياة المهنية لحل مشاكل الرعاية الصحية ، و مساعدةالأطباء في اتخاذ القرارات المهنية. لسوء الحظ ، انخفض عددهم بشكل ملحوظ في العقود الأخيرة خاصة في الدول النامية. و لكن لسوء الحظ ، انخفض عدد الباحثين بشكل ملحوظ في العقود الأخيرة وخاصة في البلدان النامية. الأهداف : أجريت هذه الدراسة لتقييم المعرفة و الأتجاه نحو البحث العلمي بين طلاب الطب بجامعة عين شمس. طرق البحث والمنهجيه: أجريت دراسة مقطعية من أكتوبر إلى نوفمبر 2016. وقد طلب من عينة متاحة من طلاب الطب من كل فرقة در اسية (الفرقة الأولي إلى الفرقة السادسة) للمشاركة. تم جمع البيانات من خلال استبيان تم إعداده مسبقًا و أختباره والتحقق من صحته ، يتكون من 3 أجزاء حول البيانات الاجتماعية الديموغر افية وأسئلة عن المعرفة والأتجاه نحو البحث العلمي. النتائج: أكمل 312 طالب استبيان بملأ ذاتيا. و قدأظهر الطلاب مستوى معتدلاً من المعرفة والأتجاه (متوسط النتيجة 43.4 + 22.5 و 45.8 + 18.6 على التوالي). وتتحسن المعرفة بشكل ملحوظ مع زيادة سنوات الدراسة (أعلى بين طلاب الفرقةالسادسة والخامسة والرابعة عن باقي الفرق الثلاثةالأولي) وكانت معرفة الطلاب الذكور أعلى من الإناث. بينما أظهر طلاب الفرقة الثالثة والأولى أتجاه عاليا نحو ممارسة البحث من الفرق الدراسية الأخري. الاستنتاجات: هناك فجوة في معرفة الطلاب و أتجاههم نحو البحث. و هنالك حاجة لتحسين مناهج التعليم الطبي القائمة لتعزيز ثقافة البحث بين الطلاب. و أيضا ، هناك حاجة لتشجيع الطلاب على إجر اء البحوث من خلال المشاركة الفعالة في مشاريع البحوث في الجامعة. الكلمات الرئيسية: المعرفة ، الأتجاه، طلاب الطب في المرحلة الجامعية ، البحث 